\title{
POTENSI PERAN PEREMPUAN DALAM MEWUJUDKAN MODERASI BERAGAMA DI INDONESIA
}

\author{
Luh Riniti Rahayu (Universitas Ngurah Rai Denpasar) dan Putu Surya Wedra Lesmana
}

(STIKI Indonesia Denpasar). Email : luhrinitirahayu@gmail.com; HP.08123873650

\begin{abstract}
ABSTRAK
Sejak berlakunya Otonomi Daerah di Indonesia, intoleransi terus meningkat diberbagai daerah, intoleransi ini mengancam kehidupan sosial dan kehidupan beragama masyarakat Indonesia. Bila hal ini terus dibiarkan berkembang maka, akan memicu perpecahan bangsa serta mengancam keberadaan NKRI. Pemerintah telah melakukan berbagai usaha guna meredam intoleransi dan memelihara kerukunan antar enam agama yang diakui Negara. Salah satunya adalah dengan cara mewujudkan moderasi beragama. Penelitian ini menyoroti Peran Perempuan dalam Moderasi Beagama di Indonesia dengan metode deskriptif kualitatif. Hasilnya adalah Perempuan dari berbagai agama sangat potensial dalam menjaga harmoni dan menjaga kerukunan antara umat beragama, namun potensi ini belum dimanfaatkan secara maksimal. Sebagai saran, perlunya meningkatkan peran dan melibatkan perempuan dalam setiap kegiatan implementasi moderasi beragama di Indonesia.
\end{abstract}

Kata Kunci : Perempuan, Toleransi, Moderasi Beragama

\section{PENDAHULUAN}

Negara Kesatuan Republik Indonesia (NKRI) kemajemukan etnis, budaya, bahasa dan agama adalah merupakan fakta dan realitas, dimana penduduk Indonesia tersebar dengan letak geografis antardaerah yang luas dipisahkan oleh ribuan pulau-pulau dari Merauke sampai ke Sabang, dan dari pulau Rote sampai ke Miangas. Bangsa Indonesia yang pluralistik dan multikulturalistik dengan keanekaragaman agama mempunyai kecenderungan kuat terhadap identitas agama masing-masing, sangat berpotensi lahirnya konflik. ${ }^{1}$

Bangsa Indonesia memang merupakan bangsa yang majemuk secara agama dan memiliki jumlah penduduk sangat besar. Dengan merujuk pada Sensus Penduduk 2010 yang merupakan sensus terakhir, jumlah penduduk Indonesia adalah 237.641.326 jiwa.

Berdasarkan hasil sensus tersebut, Islam merupakan agama yang paling banyak dianut oleh penduduk Indonesia. Sebanyak 207,2 juta jiwa (87,18 persen) penduduk Indonesia mengaku beragama Islam. Kemudian secara berturut-turut diikuti oleh penganut agama Kristen sebanyak

1 Nina Mariani Noor (ed.). 2015. Manual Etika Lintas Agama Untuk Indonesia . Geneva: Globethics.net, 2015. ISBN 978-2-940428-84-7 (online version).
16,5 juta jiwa $(6,96$ persen), penganut agama Katolik sebanyak 6,9 juta jiwa (2,91 persen), penganut Hindu sebanyak 4 juta jiwa $(1,69$ persen), penganut Buddha sebanyak 1,7 juta jiwa ( 0,72 persen), penganut Khonghucu sebanyak 0,11 juta jiwa $(0,05$ persen $)$, dan agama lainnya 0,13 persen. $^{2}$

Konflik berdasarkan intoleransi semakin meningkat, terutama sejak terjadi reformasi Tahun 1998 di Indonesia. Hasil riset yang dilakukan Setara Institute menyatakan sepanjang tahun 2018 mencatat 160 peristiwa pelanggaran kebebasan beragama/berkeyakinan (KBB) dengan 202 bentuk tindakan, yang tersebar di 25 provinsi. $^{3}$ Selain kasus penistaan agama juga terjadi konflik perebutan sumber daya ekonomi, sumber daya alam, perebutan kekuasaan antara elit, ketidak adilan, kemiskinan, ketidak berdayaan masyarakat bawah, tekanan ekonomi, kelompok yang terpinggirkan, radikalisme agama, tarik menarik

2 Sensus Penduduk terakhir oleh BPS pada tahun 2010. Sensus selanjutnya akan diselenggarakan pada Tahun 2020.

3 Siaran Pers Setara Institute. 2018. Melawan Intoleransi di Tahun Politik, Kondisi Kebebasan Beragama/Berkeyakinan dan PemajuanToleransi di Indonesia Tahun 2018. 
kepentingan pemerintah pusat dan daerah, yang semua saling terkait saling berbenturan. ${ }^{4}$

Terjadinya konflik horizonal di Poso, Madura dan Sampit menelan banyak korban, baik dari kalangan sipil bersenjata dan polisi. Peristiwa tersebut terjadi karena setiap warga bangsa kurang menyadari adanya keanekaragaman ras, suku, adat istiadat, golongan dan agama yang telah disepakati dalam "Bhinneka Tunggal Ika". Atau sudah mengetahui bahwa keberagaman SARA (suku, ras antar golongan dan agama), politiknya. Namun adanya kelompok kepentingan yang ingin mencari keuntungan dalam bidang politik, telah melakukan kekerasan dan pelanggaran HAM, dengan menggunakan isu agama, sebagai kendaraanya.

Sehubungan dengan hal tersebut, untuk mewujudkan kerukunan hidup antar umat beragama, harus tercipta sebuah konsep hidup bernegara yang mengikat semua anggota kelompok sosial yang berbeda agama untuk menghindari terjadinya konflik antar umat beragama.

Pemerintah telah berupaya merumuskan regulasi yang mengatur pola kerukunan umat beragama. Konsep "Kerukunan Hidup Beragama", pada masa Menteri Agama Mukti Ali di masa Orde Baru telah dibangun berdasarkan landasan teoritik kerukunan umat beragama di Indonesia. ${ }^{6}$ Setelah Orde Baru digantikan Orde Reformasi, terjadi banyak konflik terbuka di beberapa daerah di Indonesia. Hal ini membuat timbulnya kesadaran masyarakat dalam membangun kehidupan yang rukun dan damai. Terutama masyarakat di daerah konflik yang merasa jenuh dengan konflik yang berkepanjangan.

Banyak upaya telah dilakukan pemerintah melalui Kementerian Agama, dari membentuk

4 Rina Hermawati, Caroline Paskarina, Nunung Runiawati. Toleransi Antar Umat Beragama di Kota Bandung. UMBARA : Indonesian Journal of AnthropologyVolume 1 (2) Desember 2016 eISSN 2528-1569 pISSN 2528-2115.

5 Laporan Penelitian Wahid Institute Tahun 2017 berjudul Intoleransi dan Radikalisme dikalangan Perempuan riset lima wilayah: Bogor, Depok, Solo Raya, Malang dan Sumenep.

6 Muhammad Anang Firdaus. 2014. Eksistensi FKUB dalam Memelihara Kerukunan Umat Beragama di Indonesia. Jurnal Kontekstualita, Vol. 29, No.1, 2014.
Forum Kerukunan Umat Beragama atau FKUB sampai berbagai dialog-dialog keagamaan di tingkat nasional maupun daerah. Namun usaha tersebut masih saja terjadi konflik, bahkan konflik berbasis agama terus meningkat. Kini usaha terakhir pemerintah adalah dengan cara penguatan moderasi beragama yang diimplementasikan mulai tahun 2019 dan akan diakomodir pada RPJM 2020-2024. ${ }^{7}$

Substansi moderasi beragama di Indonesia sebenarnya bukan hal yang baru. Karena masyarakat Indonesia telah memiliki modal sosial dan kultural yang cukup mengakar. Bangsa Indonesia biasa bertenggang rasa, toleran, menghormati persaudaraan, dan menghargai keragaman. Nilai-nilai inilah yang menjadi fondasi masyarakat dalam menjalani moderasi beragama. Kini nilai-nilai yang mulai luntur ini, diperkuat melalui pengarusutamaan program moderasi disemua intitusi dan aspek kehidupan masyarakat.

Penelitian ini memakai metode deskriptif kualitatif guna menyoroti bagaimana peran perempuan Indonesia dalam mewujudkan moderasi beragama di Indonesia.

\section{MODERASI BERAGAMA DI INDONESIA}

Dalam kehidupan beragama, sering adanya istilah "Islam moderat", "Hindu Moderat", atau "Kristen moderat". Jika dikatakan, "orang itu bersikap moderat", berarti bahwa orang itu bersikap wajar, biasa-biasa saja, dan tidak ekstrem. Moderat, berasal dari kata moderasi dari Bahasa Latin moderâtio, yang berarti ke-sedangan (tidak kelebihan dan tidak kekurangan). Kata moderasi juga berati : (1) pengurangan kekerasan, dan (2) penghindaran keekstreman. ${ }^{8}$ Moderat Secara umum, berarti mengedepankan keseimbangan dalam hal keyakinan, moral, dan watak, baik ketika memperlakukan orang lain sebagai individu, maupun ketika berhadapan dengan institusi negara.

7 Kementerian Agama RI. 2019. Moderasi Beragama . Badan Litbang dan Diklat Kementerian Agama RI Gedung Kementerian Agama RI Jl.MH. Thamrin No.6 Lt. 2 Jakarta Pusat

8 Kamus Besar Bahasa Indonesia (KBBI) menyediakan dua pengertian kata moderasi. 
Dalam bahasa Inggris, kata moderation sering digunakan dalam pengertian average (ratarata), core (inti), standard (baku), atau non-aligned (tidak berpihak). Dalam bahasa Arab, moderasi dikenal dengan kata wasath atau wasathiyah, Orang yang menerapkan prinsip wasathiyah bisa disebut wasith. Wasith telah diindonesiakan menjadi wasit, yang artinya berimbang, tidak memihak dan adil. sedangkan lawan kata moderasi adalah berlebihan, atau tatharruf dalam bahasa Arab, yang mengandung makna extreme, radical, dan excessive dalam bahasa Inggris. Apa pun kata yang dipakai, semuanya menyiratkan satu makna yang sama, yaitu adil, yang dalam konteks ini berarti memilih posisi jalan tengah di antara berbagai pilihan ekstrem.

Moderasi beragama dimaknai sebagai sikap beragama yang seimbang antara pengamalan agama sendiri (eksklusif) dan penghormatan kepada praktik beragama orang lain yang berbeda keyakinan (inklusif). Sehingga keseimbangan atau jalan tengah dalam menjalankan beragama ini akan menghindarkan sikap ekstrem berlebihan, fanatik dan sikap revolusioner dalam beragama.

Prinsip keseimbangan (balance) dan adil (justice) dalam konsep moderasi berarti bahwa dalam beragama, seseorang tidak boleh ekstrem pada pandangannya, melainkan harus selalu mencari titik temu, prinsip dasar dalam moderasi beragama adalah selalu menjaga keseimbangan di antara dua hal. ${ }^{9}$

Setiap agama mengajarkan penyerahan diri seutuhnya kepada Tuhan Yang Maha Esa, sang Maha Pencipta. Penghambaan kepada Tuhan ini diwujudkan dalam kesiapan mengikuti petunjukNya dalam kehidupan. Ajaran untuk menjadi moderat bukanlah semata milik satu agama tertentu saja, melainkan ada dalam tradisi berbagai agama dan bahkan dalam peradaban dunia. Dengan demikian, moderasi beragama akan mendorong masing-masing umat beragama untuk tidak bersifat ekstrem dan berlebihan dalam menyikapi keragaman, termasuk keragaman agama dan tafsir agama, melainkan selalu bersikap adil dan berimbang sehingga dapat hidup dalam sebuah kesepakatan bersama.

\footnotetext{
${ }^{9}$ Kamali, Mohammad Hasyim, 2015. The Middle Path of Moderation in Islam, the Qur'anic Principle of Wasathiyah. Oxford: Oxford University Press.
}

Sikap moderat pada dasarnya merupakan keadaan yang dinamis, selalu bergerak, karena moderasi pada dasarnya merupakan proses pergumulan terus-menerus yang dilakukan dalam kehidupan masyarakat. Sehingga sebagai syarat moderasi beragama adalah dimilikinya pengetahuan yang luas dan mempunyai pemahaman keagamaan yang baik. Dalam konteks Indonesia, untuk dapat digunakan mengenali seberapa kuat moderasi beragama yang dipraktikkan oleh seseorang di Indonesia, serta seberapa besar kerentanan yang dimiliki terdapat indikator moderasi beragama yang digunakan, yaitu: (1) komitmen kebangsaan, (2) toleransi, (3) anti-kekerasan dan (4) akomodatif terhadap kebudayaan lokal. ${ }^{10}$ Selanjutnya dijelaskan dalam buku Moderasi Beragama, yang diterbitkan Kementerian Agama RI (2019), bahwa Indikator Komitmen kebangsaan penting guna melihat sejauh mana cara pandang, sikap, dan praktik beragama seseorang yang berdampak pada kesetiaan terhadap konsensus dasar kebangsaan. Hal ini terkait dengan penerimaan Pancasila sebagai ideologi negara, sikapnya terhadap tantangan ideologi yang berlawanan dengan Pancasila, serta nasionalisme.

Indonesia adalah negara yang multikultural, sangat beragam, sehingga dalam indikator komitmen kebangsaan ini diperlukan toleransi. Toleransi merupakan sikap untuk memberi ruang yang tidak mengganggu hak orang lain untuk berkeyakinan, mengekspresikan keyakinannya, dan menyampaikan pendapat, meskipun hal tersebut berbeda dengan apa yang kita yakini. Dengan demikian, toleransi mengacu pada sikap terbuka, lapang dada, sukarela, dan lembut dalam menerima perbedaan. Dan toleransi tidak hanya terkait dengan keyakinan agama, namun bisa terkait dengan perbedaan ras, jenis kelamin, perbedaan orientasi seksual, suku, dan budaya. ${ }^{11}$

Indikator anti kekerasan dalam konteks moderasi beragama ini dipahami sebagai suatu ideologi atau ide gagasan yang ingin melakukan perubahan pada sistem sosial dan politik dengan menggunakan cara-cara kekerasan yang ekstrem

\footnotetext{
${ }^{10}$ Kementerian Agama RI. 2019. Moderasi Beragama. Hal: 42. Badan Litbang dan Diklat Kementerian Agama Republik Indonesia. - Cet. Pertama. Jakarta: Kementerian Agama RI, 2019.

11 ibid
} 
atas nama agama, baik kekerasan verbal, fisik dan pikiran. Kekerasan atau tindakan radikalisme intinya adalah sikap dan tindakan seseorang atau kelompok tertentu yang menggunakan cara-cara kekerasan dalam mengusung perubahan yang diinginkan.

Indikator akomodatif terhadap budaya lokal dapat digunakan untuk melihat sejauh mana kesediaan untuk menerima praktik keagamaan yang mengakomodasi kebudayaan lokal dan tradisi. Dalam perilaku keagamaannya, orangorang yang moderat memiliki kecenderungan lebih ramah dalam penerimaan tradisi dan budaya lokal, sejauh tidak bertentangan dengan pokok ajaran agamanya.

Masyarakat Indonesia yang sangat plural dan multikultural terdiri dari beragam suku, etnis, agama, bahasa, dan budaya. Keragaman yang dimiliki menimbulkan adanya perbedaan, dan setiap perbedaan potensial melahirkan gesekan atau konflik, yang dapat menimbulkan ketidakseimbangan dan perpecahan. Sehubungan dengan hal tersebut moderasi beragama diperlukan untuk menciptakan keseimbangan dalam kehidupan beragama. Moderasi beragama menjaga agar dalam mempraktikkan ajaran agama, seorang pemeluk agama tidak terjebak secara ekstrem pada salah satu cara pandang beragama saja.

Moderasi beragama tidak dapat dipisahkan dari toleransi, atau toleran. Moderasi beragama adalah proses, dan jika moderasi diterapkan toleransi adalah hasil atau buah (outcome). Dalam konteks ini toleransi dapat dirumuskan sebagai sikap keterbukaan untuk mendengar pandangan yang berbeda, dengan cara mengemukakan pandangan dan menerima pandangan dalam batas-batas tertentu namun tidak merusak keyakinan agama masing-masing. Toleransi merupakan salah satu indikator paling signifikan untuk menciptakan kerukunan umat beragama, yaitu sebuah kondisi kehidupan umat beragama yang berinteraksi secara harmonis, toleran, damai, saling menghargai, dan menghormati perbedaan agama dan kebebasan menjalankan ibadat masingmasing. ${ }^{12}$

Sejak Indonesia Merdeka, apalagi sejak masa pemerintahan orde baru, banyak kebijakan

\footnotetext{
12 Dalam Indeks Kerukunan Umat Beragama (KUB yang diterbitkan oleh Puslitbang Bimas Agama dan Layanan Keagamaan (2019)
}

dan regulasi yang dibuat pemerintah melalui Kementerian Agama, guna membangun dan merawat toleransi beragama di Indonesia. Namun ternyata tidak sepenuhnya meningkatkan sikap moderat dalam beragama dan tidak mampu menghindarkan konflik. Namun bila regulasi keagamaan tersebut dihilangkan, maka konflikkonflik keagamaan tentu akan lebih banyak lagi terjadi.

Pada masa kepemimpinan Menteri Agama Lukman Hakim Saifuddin, upaya penguatan moderasi beragama dilakukan secara sistematis dan berkelanjutan, yaitu melalui 3 (tiga) strategi : (a) sosialisasi dan diseminasi gagasan moderasi beragama, (b) pelembagaan moderasi beragama ke dalam program dan kebijakan yang mengikat dan (c) pengintegrasian perspektif moderasi beragama ke dalam Rencana Pembangunan Jangka Menengah Nasional (RPJMN) 2020-2024.

Usaha mengimplementasikan strategi penguatan moderasi kementerian agama ini tidaklah mudah. Karena pemahaman dan konsep dari moderasi belum banyak diketahui. Dalam konteks beragama di Indonesia kata Moderat adalah sebuah kata yang sering disalahpahami. Banyak masyarakat yang beranggapan bahwa seseorang yang bersikap moderat dalam beragama berarti tidak teguh pendiriannya, tidak serius, atau tidak sungguh-sungguh dalam mengamalkan ajaran agamanya.

Di kalangan masyarakat bahwa, berpihak pada nilai-nilai moderasi dan toleransi dalam beragama disamakan dengan bersikap liberal dan mengabaikan norma-norma dasar yang sudah jelas tertulis dalam teks-teks keagamaan. Mereka yang beragama secara moderat sering dianggap dengan umat yang melawan kaum konservatif yang berpegang teguh pada ajaran agamanya.

\section{PEREMPUAN DAN MODERASI BERAGAMA}

Indonesia adalah negara dengan keragaman etnis, suku, budaya, bahasa, dan agama yang nyaris tiada tandingannya di dunia. Selain enam agama yang paling banyak dipeluk oleh masyarakat, yaitu: Islam, Kristen Khatolik, Kristen Protestan,Hindu, Budha, dan Konghucu. Selain itu ada ratusan suku, bahasa dan aksara daerah, serta kepercayaan lokal di Indonesia. Badan Pusat Statistik (BPS) tahun 2010, secara keseluruhan jumlah suku dan sub suku di Indonesia adalah sebanyak 1331, pada tahun 2013 
jumlah ini berhasil diklasifikasi oleh BPS sendiri, yang bekerja sama dengan Institute of Southeast Asian Studies (ISEAS), menjadi 633 kelompokkelompok suku besar. Dari semua suku yang berada di Indonesia tersebut, jumlah penduduk laki-laki dan perempuan adalah berimbang. Dengan demikian dalam konteks keindonesiaan, perempuan tidak bisa diabaikan, karena merupakan setengah dari jumlah penduduk.

Dengan kondisi seperti di atas, guna mempertahankan keberadaan NKRI dan mewujudkan kedamaian dalam keberagaman maka, sangatlah dibutuhkan adanya toleransi. Toleransi adalah istilah dalam konteks sosial, budaya dan agama yang berarti sikap dan perbuatan yang melarang adanya diskriminasi terhadap kelompok-kelompok yang berbeda atau tidak dapat diterima oleh mayoritas dalam suatu masyarakat. ${ }^{13}$ Begitu pula dalam toleransi terdapat pengakuan adanya kebebasan setiap warga untuk memeluk agama yang diyakininya. Toleransi beragama dapat direlealisasikan dalam bentuk : (1) setiap penganut agama mengakui eksistensi agama-agama lain dan menghormati hak asasi penganutnya. (2) setiap golongan umat beragama menampakkan sikap saling mengerti, menghormati dan menghargai.

Perempuan mempunyai potensi besar dalam membangun dan memelihara toleransi yang diperlukan oleh Indonesia yang sangat beragam ini. Karena secara psikologis perempuan dalam perannya sebagai ibu, berhubungan secara intens dengan anaknya dan selalu bekerja sama, mampu memupuk sikapnya untuk tidak mementingkan diri sendiri, sabar, keibuan, dan rela berkorban. Dengan memiliki sikap-sikap tersebut menjadikan perempuan selalu siap menyesuaikan diri, mempertimbangkan alternative atau kemungkinan-kemungkinan lain dan mampu melihat perbedaan-perbedaan yang ada dilingkungannya. ${ }^{14}$

13 Nazmudin. 2017. Kerukunan dan Toleransi Antar Umat Beragama dalam Membangun Keutuhan Negara Kesatuan Republik Indonesia (NKRI). Journal of Government and Civil Society, Vol. 1, No. 1, 23-39.

14 Muntago, Asheley. 1972. Hal 52. The Genius Woman as the Genius humanity, dalam Woman Liberation, Michel E. Edelstein (ed.), New York : St Martin's Press
Menurut Yohana E. Prawitasari, Perempuan mempunyai potensi kehidupan sosial atau kemampuan-kemampuan sosial sebagai berikut : (1) perempuan mampu menerima dirinya sebagaimana adanya. (2) perempuan mampu terbuka terhadap pengalaman. (3) perempuan mampu bersifat asertif. (4) perempuan tahu apa yang ia kehendaki. (5) perempuan berani mempertahankan haknya. (6) perempuan mulai menggunakan keperempuanannya sebagai aset. (7) perempuan berani menunjukkan kemampuannya. (8) perempuan selalu berusaha untuk meningkat kepercayaan dirinya melalui latihan-latihan. ${ }^{15}$ Janet Zullennger Grele juga mengemukakan bahwa perempuan cenderung lebih suka bekerja sama daripada menominasi dan lebih suka menciptakan perdamaian dari pada membuat konflik. ${ }^{16}$

Para ahli Psikologi menyebutkan 4 (empat) komponen pokok emosi keibuan dari perempuan yaitu : (1) altruisme, yaitu satu sifat yang cenderung untuk mendahulukan pentingan orang lain dari pada kepentingannya sendiri dan ada perasaan cinta terhadap orang lain. (2) kelembutan. (3) kasih sayang dan (4) aktivitas. ${ }^{17}$ Komponen-komponen tersebut akan menimbulkan satu iklim psikis dan sifat keibuan. Sifat keibuan ini menyangkut dengan keberadaan anaknya sebagai satu kesatuan psikologis, dimana altruisme keibuan mendorong seorang perempuan untuk tidak rnementingkan diri sendiri dan senantiasa bersedia mengorbankan segala sesuatunya untuk kelestarian lingkungannya, dalam hal ini adalah anaknya. ${ }^{18}$

Sesuai pendapat-pendapat di atas maka perempuan mempunyai sumber daya dan memiliki potensi yang besar dalam persoalan

15 Prawitasari, Yohana E. 1993. Dalam Maimanah. 2013. Wanita dan Toleransi Beragama (Analisis Psikologis). Mu'Jurnal Studi Gender dan Anak Vol. 1 No. 1, Januari-Juni 2013.

16 Grele, Janet Zullenger. 1979. Woman and Future. New York : MacMillan Publishing Free Press.

${ }^{17}$ Maimanah. 2013. Wanita dan Toleransi Beragama (Analisis Psikologis). Mu'Jurnal Studi Gender dan Anak Vol. 1 No. 1, Januari-Juni 2013, 51-58

${ }^{18}$ Kartini Kartono. 1992. Psikologi Wanita : Mengenal Wanita sebagai Ibu dan Nenek. Bandung : CV Mandar Maju.Keluarga sebagai unit terkecil akan lebih efektif menyampaikan pesan-pesan moral upaya penyebaran gagasan moderasi. 
toleransi beragama, karena perempuan adalah makhluk sosial yang mempunyai kemampuan untuk selalu menyesuaikan diri dengan lingkungannya. Dalam konteks Indonesia, untuk dapat mewujudkan dan mengimplementasikan moderasi beragama terdapat empat indikator yaitu : 1) komitmen kebangsaan; 2) toleransi; 3) anti-kekerasan; dan 4) akomodatif terhadap kebudayaan lokal. Dimana toleransi merupakan salah satu indikator paling signifikan untuk menciptakan kerukunan umat beragama. Oleh karena itu perempuan yang mempunyai potensi besar menyangkut toleransi sangatlah signifikan untuk diikutsertakan. Dengan demikian, sangat diperlukan melibatkan perempuan secara aktif dalam usaha mewujudkan masyarakat beragama yang toleran.

\section{PENUTUP}

Moderasi beragama di Indonesia dimaknai sebagai sikap beragama yang seimbang antara pengamalan agama sendiri (eksklusif) dan penghormatan kepada praktik beragama orang lain yang berbeda keyakinan (inklusif). Sehingga keseimbangan atau jalan tengah dalam menjalankan beragama ini akan menghindarkan sikap ekstrem berlebihan, fanatik dan sikap revolusioner dalam beragama. Dalam mewujudkan moderasi beragama di Indonesia telah disosialisasikan dan dicanangkan pemerintah pada tahun 2019 dan akan diimplementasikan dalam RPJM 2020-2024. Perempuan adalah setengah dari jumlah penduduk Indonesia, perempuan mempunyai sifat-sifat sosial seperti tidak egosentris, tidak suka mendominasi, penuh kasih sayang, menyukai perdamaian dan sifat-sifat lainnya yang membawa perempuan pada predikat sebagai makhluk sosial.

Perempuan memiliki potensi besar dalam membentuk dan memelihara toleransi sehingga perempuan dapat menjadi aktor utama untuk menyemai benih moderasi dalam keluarga untuk mencegah tersebarnya ideologi kekerasan.

\section{DAFTAR PUSTAKA}

Badan Pusat Statistik. 2010. Sensus Penduduk 2010. Diunduh Tanggal 1 Oktober 2010 dari

https://sp2010.bps.go.id/index.php/publikas i/index
Badan Litbang dan Diklat Puslitbang Kehidupan Keagamaan, Pemetaan Kerukunan Kehidupan Beragama di Berbagai Daerah di Indonesia, Mursyid Ali, ed. Jakarta: Maloho Jaya Abadi Press, 2009.

Firdaus, Muhammad Anang. 2014. Eksistensi FKUB dalam Memelihara Kerukunan Umat Beragama di Indonesia. Jurnal Kontekstualita, Vol. 29, No.1.

Hermawati, Rina. Caroline Paskarina, Nunung Runiawati. 2016. Toleransi Antar Umat Beragama di Kota Bandung. UMBARA : Indonesian Journal of Anthropology Volume 1 (2) Desember 2016. eISSN 2528-1569 pISSN 2528-2115.

Grele, Janet Zullenger. 1979. Woman and Future. New York : MacMillan Publishing Free Press.

Kementerian Agama RI. 2019. Moderasi Beragama. Jakarta: Badan Litbang dan Diklat Kementerian Agama Republik Indonesia. - Cet. Pertama, 2019.

Kementerian Agama RI. 2019. Indeks Kerukunan Umat Beragama. Jakarta: KUB Puslitbang Bimas Agama dan Layanan Keagamaan 2019.

Kamali, Mohammad Hasyim. 2015. The Middle Path of Moderation in Islam, the Qur'anic Principle of Wasathiyah. Oxford: Oxford University Press.

Kartini Kartono. 1992. Psikologi Wanita: Mengenal Wanita sebagai Ibu dan Nenek. Bandung: CV Mandar Maju.

Laporan Penelitian Wahid Institute. 2017. Intoleransi dan Radikalisme dikalangan Perempuan riset lima wilayah: Bogor, Depok, Solo Raya, Malang dan Sumenep. Diunduh pada 1 Oktober 2019 dari : http://wahidfoundation.org/index.php/publi cation/index/report

Maimanah. 2013. Wanita dan Toleransi Beragama (Analisis Psikologis). Mu'Jurnal Studi Gender dan Anak Vol. 1 No. 1, Januari-Juni 2013, 51-58.

Muntago, Asheley. 1972. Hal 52. The Genius Woman as the Genius humanity, dalam Woman Liberation, Michel E. Edelstein (ed.), New York : St Martin's Press 
Nazmudin. 2017. Kerukunan dan Toleransi Antar Umat Beragama dalam Membangun Keutuhan Negara Kesatuan Republik Indonesia (NKRI). Journal of Government and Civil Society, Vol. 1, No. 1, 23-39.

Nina Mariani Noor (ed.). 2015. Manual Etika Lintas Agama Untuk Indonesia .

Geneva: Globethics.net, 2015. ISBN 978-2940428-84-7 (online version).

Siaran Pers Setara Institute. 2018. Melawan Intoleransi di Tahun Politik, Kondisi
Kebebasan Beragama/Berkeyakinan dan PemajuanToleransi di Indonesia Tahun 2018. Jakarta : 31 Maret 2019. Diunduh tanggal 1 Oktober 2019 dari http://setarainstitute.org/melawan-intoleransi-di-tahunpolitik/

Tim Penyusun, Kamus Besar Bahasa Indonesia. Jakarta : Depdiknas dan Balai Pustaka, 2005. 